\title{
FIRST RECORD ON ODONTANTHIAS FLAGRIS YOSHINO AND ARAGA, 1975 (PERCIFORMES: SERRANIDAE) IN INDONESIAN WATERS
}

\author{
Teguh Peristiwady \\ Technical Implementation Unit for Marine Biota Conservation \\ Research Centre for Oceanography, Indonesian Institute of Sciences (LIPI) \\ Jln. Tandurusa, Kel. Tandurusa, Kec. Aertembaga, \\ Bitung 95527, North Sulawesi, Indonesia \\ E-mail: ikan_teguh@yahoo.com
}

Received: October 2010

Accepted: February 2011

\begin{abstract}
Two specimens of Odontanthias flagris have been caught from Bitung, North Sulawesi in June 2010. Previously, nown locations of this species are Okinawa and Nishino-shima, Japan. O. flagris is very similar with O. rhodopeplus. They shares following characters: dorsal fin rays X, 13; anal fin rays III, 7; pectorals fin rays 17-18; scales above lateral line 7; scales below lateral line 19 and gill rakers on lower limb 28. Characters differing $O$. flagris from $O$. rhodopeplus, $O$. chrysostictus and other six species appear in the percentage of orbit diameter. In addition, $O$. flagris has shorter pelvic fin rays but longer caudal peduncle and third dorsal fin spine. Its morphological features, distribution, remarks and photo of species are given in this paper.
\end{abstract}

Keywords: Odontanthias flagris, Serranidae, Anthiinae, Indonesia

\section{INTRODUCTION}

Fishes of the genus Odontanthias are small size species living in rugged-bottom habitat beyond scuba-diving depths, and have no or little commercial value (Randall, 1996; Chen and Shao, 2002; Randall and Heemstra, 2006). Therefore it is rarely catched by divers, gill-netting or trawling, and is not well represented in museum collections (Randall, 1996; Chen and Shao, 2002).

Members of this genus had previously been considered belong to the genus Holanthias (Heemstra \& Randall, 1986), but they differ from this eastern Atlantic genus in having a lunate or deeply emarginate caudal fin (vs. near-truncate to rounded or rhomboid) and no accessory scales on the body (vs. numerous accessory scales on body) (White, 2011). The genus Odontanthias Bleeker is characterized as follows: dorsal fin rays $\mathrm{X}, 12-19$; anal fin rays III,7-8; pectoral fin rays 15-19; lateral line complete or incomplete; vertebrae 26; interorbital space convex; mouth not large; tongue, vomer, palatines and mesopterygoids with a large patches of small villiform teeth; posterior margin of preopercle strongly serrate with a prominent flat spine or enlarge spine at the angle; and body depth 1.9-2.7, head length $2.35-2.85$ both in standard length (SL) (Randall and Heemstra, 2006).

Thirteen (13) species of Odontanthias have been reported from Indo-Pacific region (Randall and Heemstra, 2006), whereas Indonesian waters have five species: $O$. borbonius, $O$. chrysostictus, $O$. randalli, O. rhodopeplus and O. unimaculatus (Masuda et al., 1984; Smith and Heemstra, 1986; Kimura et al., 2003; Kuiter and Debelius, 2006; Randall and Heemstra, 2006; Peristiwady 2006; 2011 and White, 2011). O. flagris found in Bitung (North Sulawesi, Bitung) brings the total species number of this genus known in Indonesian waters to six species. 


\section{MATERIALS AND METHODS}

Two specimens of Odontanthias flagris were collected from Girian fish markets, Bitung, North Sulawesi, Indonesia. Specimens were photographed in fresh condition and then preserved in $10 \%$ formalin for about one week. Afterwards, they were transferred into $70 \%$ ethanol for further examination and permanent preservation.

Meristic and morphometric methods generally followed Randall and Heemstra (2006) with several additional measurements (all spines and rays length of dorsal and anal fins and suborbital width). All measurements were made with digital calipers to the nearest $0.01 \mathrm{~mm}$.

The fish proportion length measured were reported as standard lengths (SL) and body depth (BD). The specimens have been deposited at the Technical Implementation Unit for Marine Biota Conservation, Research Centre for Oceanography, LIPI, Bitung (North Sulawesi). Institutional code followed Fricke and Eschmeyer (eds) (2012), except for LBRC-F which stands for LIPI Bitung Reference Collection-Fish. Valid record of the fish specimen referred to the data from Eschmeyer \& Fricke (eds.) (2012).

\section{RESULTS AND DISCUSSION}

Daily visits during 2010 at Girian fish market (Bitung, South Sulawesi) brought opportunity to find and collect two specimens of Odontanthias flagris Yoshino and Araga, 1975 (Figure 1; Table 1). This species has never been recorded in Indonesian waters before.

Due to its preference for relatively deep water and because of their occurrence over or inside hard substrate, they cannot apt to be taken by fishermen using trawls or gill-net. The anthiine specimens in this study were taken using hook and line by fishermen targeting deep water groupers or snappers such as Epinephelus, Pristipo-moides and Etelis.

\section{Taxonomy}

Odontanthias flagris Yoshino and Araga, 1975

English name: Anthiine fish

Indonesian standard name: Nona Manis Bendera.
Odontanthias flagris Yoshino and Araga in Masuda et al. (1975): 219, pl. 51, figure B (holotype, type locality, Okinawa); Randall and Heemstra (2006): 15, pl. III B, Tables 1-3, figures. 1 F, 3 .

Material examined. LBRC-F 1574, $136.9 \mathrm{~mm}$ $\mathrm{SL}$, no data on depth, hook and line, Girian, Bitung, North Sulawesi, Indonesia, June $2^{\text {th }}, 2010$, collected by T. Peristiwady; LBRC-F 001575, $149.5 \mathrm{~mm}$ SL, same data as LBRC-F 001574; URMP 0505, (non-type specimen), $179.5 \mathrm{~mm} \mathrm{SL}$, Ryukyu Islands, Okinawa, Japan, collected by T. Yoshino; URMP (label loss), (non-type specimen), 189.5 mm SL, Ryukyu Islands, Okinawa, Japan, collected by T. Yoshino; URMP 0506, (non-type specimen), $191.5 \mathrm{~mm}$ SL, Ryukyu Islands, Okinawa, Japan, collected by T. Yoshino.

Description. Measurements and counts are shown in Table 1. Dorsal fin rays X, 18; anal fin rays III, 7; all dorsal and anal fin rays branched, the last joined to the base; pectoral fin rays $17-18$, uppermost two rays and lowermost ray unbranched; pelvic fin rays I, 5, all rays branched; lateral line scales 42-43; scales above lateral line to origin of dorsal fin 8; scales below lateral line to origin of anal fin 22; scales above lateral line to base of middle dorsal fin 3 ; oblique rows of scales on check 7-8; gill rakers 11- (28-29) (total gill rakers 39-40).

Body deep and compressed, the width 37.19-42.57 in BD; head length: 22.39-24.07 all in SL; eye large, the orbit diameter: 26.9-29.1 in HL; snout length 22.51-24.2 in HL; interorbital space convex, the least bony width $26.9-29.1$ in HL; least caudal peduncle depth $39.39-40.21$ in HL; caudal peduncle length 65.69-68.51 in HL.

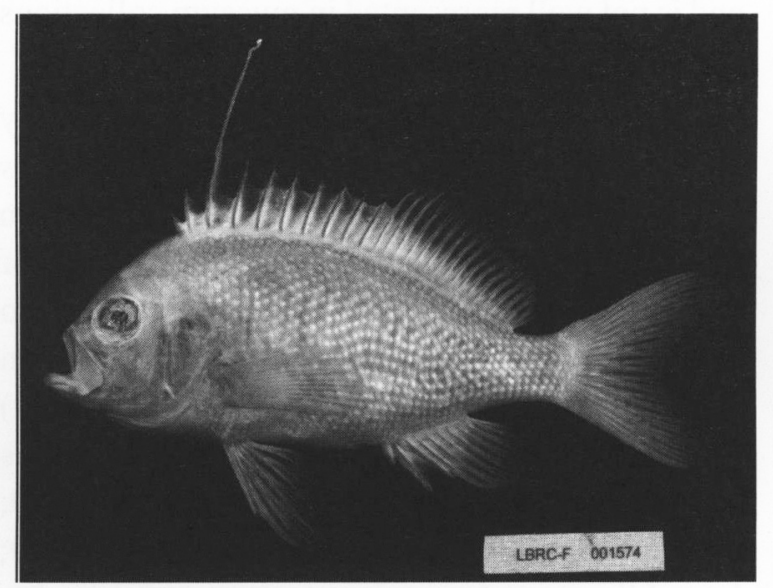

Figure 1. Odontanthias flagris, LBRC-F 1574, 136.9 $\mathrm{mm}$ SL. 
Mouth terminal, oblique and not large, forming an angle of ca. $60^{\circ}$ to horizontal line of head, the lower jaw projecting; maxilla reaching slightly anterior to a vertical through center of pupil, the upper jaw length 43.82-44.32 in HL; each anterior of upper jaw with a pair of stout canine teeth, inner upper jaw and lower jaw with rows of minute teeth, outer rows with several teeth longer than inner teeth, half distance of lower jaw with 2-3 stout and recurved canines. Nostrils are slightly upper of horizontal line passing center of pupil, the flap almost reaches the anterior of nostril aperture; sensory pore found below and in front of anterior nostril, other sensory pores at around lachrymal, infra-orbital and below lower jaw.

Opercle with three flat spines, middle one largest and tip, slightly closer to lower than upper spine; upper opercular spine blunt; posterior margin of preopercular edge of preopercle with 27, angle of preopercle with a large flat spine about more than one third way to margin of subopercle; serrae on ventral edge of preopercle $0-1$; margin of subopercle with $2-6$, margin of interopercle with 2, opercular flap pointed.

Lateral line complete, broadly arched over pectoral fin closed to dorsal fin base, running parallel to dorsal body contour below dorsal fin of $6^{\text {th }}$ spine; its highest point below base of $8^{\text {th }}$ dorsal spine.

Scales ctenoid; predorsal part of head scaled anteriorly reaching base of upper lip; maxilla and mandible scaled; preorbital from nostrils to below front of orbit naked; small scales on base of all fins; scales on two upper and lower lobes caudal fin rays almost reaching tip, base of the middle caudal fin with scales to about one third of caudal fin; base of pectoral and anal fins with small scales.

Origin of dorsal fin above the post-temporal, predorsal length 91.93-94.40 in HL; first dorsal spine short 55.38-57.55 in second dorsal spine, second dorsal spine $21.25-24.13$ in third dorsal spine; third dorsal spine longest, 121.67-148.48 in HL; third dorsal ray longest forming filament, 67.27-84.94 in HL; origin of anal fin beneath third dorsal ray; first anal spine 52.04-58.12 in length of second spine; second anal spine slightly shorter than third, 92.21-93.05 in length of third spine; second or third anal ray longest, 67.11-71.94 in HL; caudal fin deeply emarginated, the upper and lower lobes not forming filament, the fin length $102.00-103.88$ in SL; caudal concavity 9.37-11.24 in SL; pectoral fin not pointed, the tenth ray longest, reaching base of anus, 93.48-94.50 in HL; origin of pelvic fin on a vertical through between base of third and fourth dorsal spine; second pelvic ray longest, the length 55.38-57.55 in HL.

Color when fresh (Figure 1): body pink with a yellow pink dorsally, pale pink ventrally, with a yellow blotches running from interorbital space to anterior of dorsal fin base; a second yellow stripe from upper lip, passing suborbital space to above the biggest flat spine at opercle; body with posterior margin of scales whitish; yellow bright botches at pectoral fin base; spinous portion of dorsal fin pale pink, upper part of dorsal spine portion with a large pale yellow area from the first to anterior part of dorsal fin rays; incised portion of dorsal spine bright pink, basal soft portion of dorsal fin pale pink, the outer part pale yellow; pectoral fin pale pink; inner rays of pelvic fins pale pink, outer rays yellow, pelvic spine pale pink; anal fin yellowish; other rays and membranes pale pink; caudal fin pink, each lobe yellow stripe at inner and outer lobe.

Color after preservation: head and body uniformly pale whitish, posterior tip of scales on body whitish forming a horizontal and diagonal lines.

Distribution and ecological notes: Initially this species was described as new species from Okinawa, Japan from the depth of about 70-80 $\mathrm{m}$. All specimens both from Japan and Indonesia had long third dorsal spine. This species from other locations was reported from Nishino-shima, Ogasawara Islands (Randall and Heemstra, 2006) and was now recorded also in Bitung, Sulawesi Island, Indonesia (Figure 2).

Remarks: The meristic data of Odontanthias flagris was most similar to $O$. rhodopeplus, sharing the following characters: dorsal fin rays $\mathrm{X}, 13$, anal fin rays III, 7 , pectorals fin rays $17-18$, scales above lateral line 7; scales above lateral line 19 and gill rakers on lower limb 28. If dorsal, anal and pelvic fin shape and coloration were ignored, $O$. flagris would seem most closely related to $O$. katayamai by body proportion and caudal fin shape. The body proportions data among $O$. rhodopeplus, O. chrysostictus and $O$. flagris were 
Table 1. Count and Measurement of Odontanthias flagris, expressed as percentages of the body depth and Mean Value between brackets

\begin{tabular}{|c|c|c|}
\hline & Japanese Specimen $n=3$ & Indonesian Specimen $\mathrm{n}=\mathbf{2}$ \\
\hline Standard length (mm) & $179.50-191.50(186.83)$ & $136.88-149.50$ (143.19) \\
\hline Dorsal fin rays & $(X, 17-18)$ & $(X, 18)$ \\
\hline Anal fin rays & $(\mathrm{III}, 7)$ & $(I I I, 7)$ \\
\hline Pectoral fin rays & $17-18(17.67)$ & 17-18 (17.5) \\
\hline Pelvic fin rays & $(1,5)$ & $(1,5)$ \\
\hline Scales on lateral line & $41-44(42.33)$ & $42-43(42.5)$ \\
\hline Scales above lateral line & $8-8.5(8.33)$ & $8-8(8)$ \\
\hline Scales below lateral line & $20-21(20.33)$ & $22-22(220)$ \\
\hline Gill rakers on upper limb & $11-11(11.00)$ & $11-11(11)$ \\
\hline Gill rakers on lower limb & $28-29(28.67)$ & $28-29(28.5)$ \\
\hline Total gill rakers & $39-40(39.67)$ & $39-40(39.5)$ \\
\hline Head length & $76.48-82.97(79.40)$ & $75.78-78.08$ (76.93) \\
\hline Body width & $37.93-42.40(40.41)$ & $37.19-42.57(39.88)$ \\
\hline Predorsal length & $66.89-74.74(72.03)$ & 69.66-73.71 (71.69) \\
\hline Prepelvic length & 85.85-99.13 (91.47) & $85.31-86.22(85.77)$ \\
\hline Preanal length & $150.24-166.58(158.61)$ & $151.63-153.10(152.36)$ \\
\hline Dorsal-fin base length & 159.10-178.68 (171.62) & $157.23-160.79$ (159.01) \\
\hline Anal-fin base length & $43.31-48.35(45.13)$ & $43.33-45.62(44.48)$ \\
\hline Pectoral-fin length & $73.82-77.50(76.07)$ & $70.84-73.79(72.31)$ \\
\hline Pelvic-fin length & $64.71-71.25$ (68.91) & $66.00-67.81(66.91)$ \\
\hline Caudal-peduncle depth & $30.86-31.80(31.42)$ & $29.85-31.39$ (30.62) \\
\hline Caudal-peduncle length & $56.13-64.73(59.56)$ & $51.29-51.92(51.60)$ \\
\hline 1th dorsal-fin spine & $13.99-16.05$ (15.28) & $13.65-14.25$ (13.95) \\
\hline 2nd dorsal-fin spine & $21.37-22.57(22.06)$ & $22.25-24.64(23.44)$ \\
\hline 3rd dorsal-fin spine & 168.15-192.65 (182.96) & $92.20-115.93(104.07)$ \\
\hline 4th dorsal-fin spine & $26.39-30.76(29.07)$ & $30.97-33.03(32.00)$ \\
\hline 5th dorsal-fin spine & $29.63-31.89(30.76)$ & $31.80-34.97$ (33.39) \\
\hline 6th dorsal-fin spine & $31.58-32.76(32.17)$ & $31.08-34.00(32.54)$ \\
\hline 7th dorsal-fin spine & $31.50-32.68$ (32.09) & $31.50-32.05(31.78)$ \\
\hline 8th dorsal-fin spine & $30.79-31.49$ (31.14) & $30.96-32.27(31.61)$ \\
\hline 9th dorsal-fin spine & $31.49-32.37(31.93)$ & $31.29-31.63(31.46)$ \\
\hline 10th dorsal-fin spine & $28.51-31.41(30.41)$ & $31.63-32.12(31.87)$ \\
\hline 1 th dorsal fin rays & $13.99-41.08(30.71)$ & $40.30-44.76(42.53)$ \\
\hline Longest dorsal fin rays (3th) & $45.20-49.80(46.95)$ & $52.52-64.37(58.44)$ \\
\hline Last dorsal fin rays & $18.61-19.52(19.10)$ & $16.92-17.26$ (17.09) \\
\hline 1th anal fin spine & $17.78-19.60(18.61)$ & $18.02-18.82(18.42)$ \\
\hline 2nd anal fin spine & $32.96-35.92$ (34.59) & $32.38-34.62(33.50)$ \\
\hline 3rd anal fin spine & $35.47-39.14(37.81)$ & $34.79-37.55(36.17)$ \\
\hline Longest anal rays (3th) & $52.77-58.57(55.83)$ & $52.40-54.52(53.46)$ \\
\hline Caudal fin length & $73.70-97.51(85.43)$ & $77.29-81.10(79.20)$ \\
\hline Pelvic spine length & $42.51-47.25(45.25)$ & $43.24-43.61(43.42)$ \\
\hline Snout length & $17.64-19.11(18.38)$ & $17.06-18.90(17.98)$ \\
\hline Orbit diameter & $18.14-22.21(20.72)$ & $23.15-23.80(23.48)$ \\
\hline Interorbital width & $21.55-22.69(22.06)$ & $20.39-22.72(21.55)$ \\
\hline Upper jaw length & $31.28-34.44$ (32.73) & $33.21-34.61$ (33.91) \\
\hline Caudal concavity & $31.54-44.85$ (36.82) & $29.50-39.19$ (34.35) \\
\hline
\end{tabular}




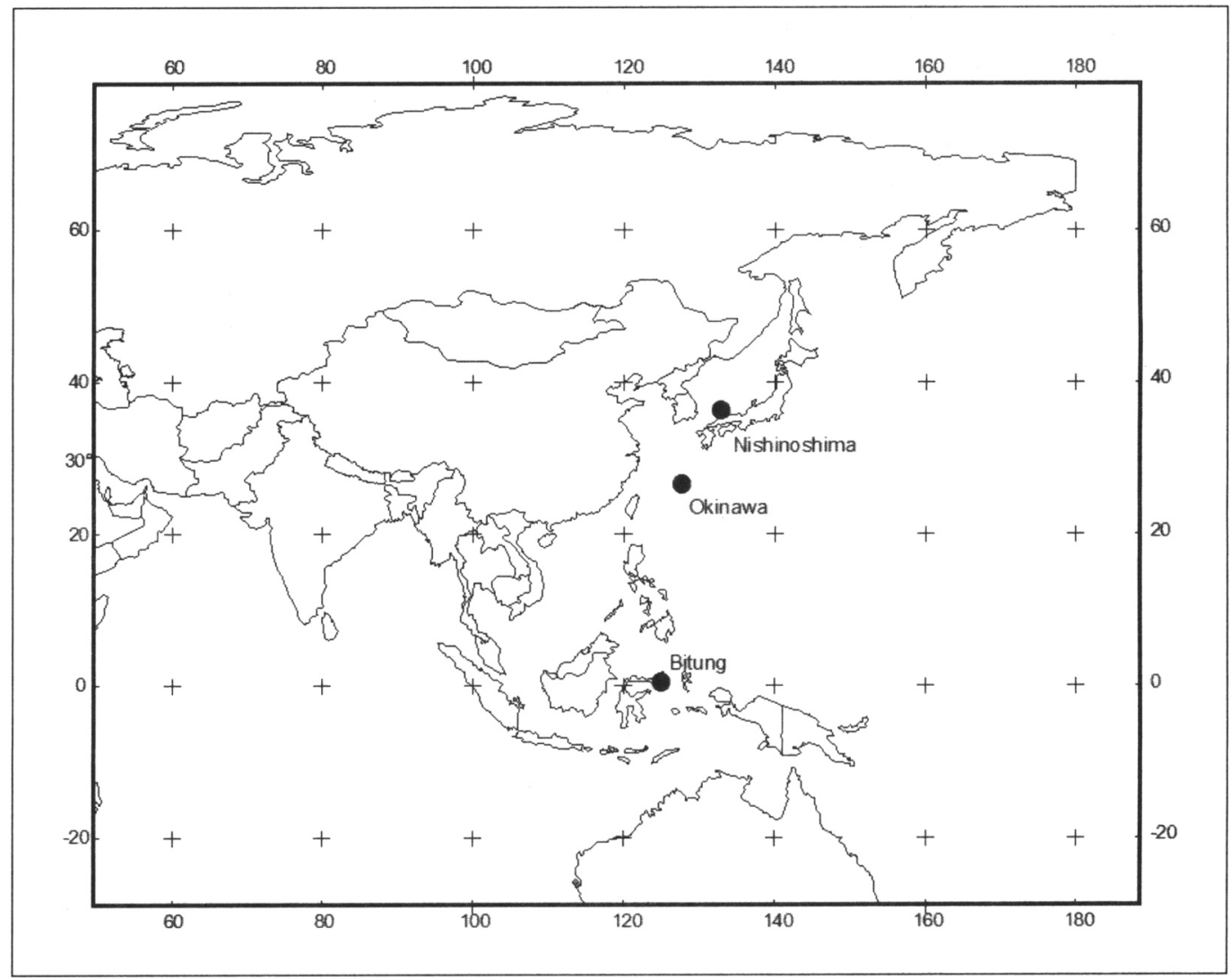

Figure 2. Geographic distribution of Odontanthias flagris

about the same proportion on percentage of head length (Figure 3A), upper jaw length (Figure 3B) and orbit diameter (Figure 3C). However the later species showed lower pelvic fin length (Figure 3D) but longer caudal peduncle length and third dorsal length (Figure 3E-F).

Comparative materials and measurements data: O. chrysostictus: LBRC-F 001392, 133.3 $\mathrm{mm}$ SL, no data on depth, hook and line, Fish market Girian, Bitung, North Sulawesi, Indonesia, 15 December 2009, collected by T. Peristiwady; LBRC-F 001287, $109.66 \mathrm{~mm} \mathrm{SL}$, no data on depth, hook and line, Batuputih, Bitung, North Sulawesi, Indonesia, 16 October 2009, collected by T. Peristiwady; FRLM 34846, $134.23 \mathrm{~mm} \mathrm{SL}$, no data on depth, hook and line, Bitung, North Sulawesi, Indonesia, 13 November 2008, collected by S. Kimura, H. Sakakibara and T. Peristiwady; O. dorsomaculatus: HUMZ 74194, $134 \mathrm{~mm}$ SL, Saya de Malha Bank, 120 m, 3 September 1977; HUMZ 73951, 110 mm SL, Saya de Malha Bank, 120 m, 2 September 1977 (Katayama and Yamamoto 1986); O. flagris, URMP 0505, (Non type specimen), 179.5 mm SL, Ryukyu Islands,
Okinawa, Japan, URMP NO LABEL, (Non type specimen), $189.5 \mathrm{~mm}$ SL, Ryukyu Islands, Okinawa, Japan, URMP 0506, (Non type specimen), 191.5 mm SL, Ryukyu Islands, Okinawa, Japan; O. grahami: AMS I.32142-010, 94 mm SL, Australia, 126-130 m, collected by Ken J. Graham, 16 February 1991 (Randall and Heemstra 2006); O. katayamai: BPBM 8527, $163 \mathrm{~mm} \mathrm{SL}$, Mariana Islands, Guam, collected by Fish and Wildlife, Government of Guam, 20 June 1968 (Randall et al. 1979); BPBM 5848, $126.5 \mathrm{~mm}$ SL, Mariana Islands, $300 \mathrm{~m}$, collected by Fish and Wildlife, Government of Guam, 7 April 1967 (Randall et al. 1979); URB 78-0148, 145 mm SL, Ryukyu Islands, more than $100 \mathrm{~m}$, collected by T. Yoshino, 6 June 1973 (Randall et al. 1979); MNHN1978/136, 150.7 mm SL, Ryukyu Islands, collected by T. Yoshino, August 1973 (Randall et al. 1979); O. rhodopeplus: UMRP 37795, 167.5 $\mathrm{mm}$, Fish market Okinawa, no data on depth, collected by T. Yoshino; UMRP 0492, 160.5 $\mathrm{mm}$, Fish market, Okinawa, no data on depth, collected by T. Yoshino; UMRP 10524, $159 \mathrm{~mm}$, Fish Market Okinawa, no data on depth, collected 
by T. Yoshino; O. tapui: MNHM 1978/459, 141 mm, Society Islands, Tahiti, about $300 \mathrm{~m}$, collected by Jean Tapu, April 1975 (Randall et al. 1979); RUSI 4680, 157 mm SL, Cook Islands, collected by Ronald Powell, July 1964; BPBM 17345, 127 mm SL, Society Islands, Tahiti, collected by Anthony Nahacky, 1973 (Randall et al. 1979); O. unimaculatus: LBRC-F 1391, $93.73 \mathrm{~mm} \mathrm{SL}$, Girian Fish Market, 14 December 2009; LBRC-F
1394, $101.71 \mathrm{~mm}$ SL, Girian Fish Market, 14 December 2009; LBRC-F 1635, $94.21 \mathrm{~mm} \mathrm{SL}$, Girian Fish Market, 29 July 2010; LBRC-F 1704, 116.52 mm SL, Girian Fish Market, 17 September 2009; LBRC-F 1715, 110.8 mm SL, Girian Fish Market, 20 September 2009; LBRC-F 1738, 103.44 mm SL, Girian Fish Market, 25 September 2010; LBRC-F 1747, 97.69 mm SL, Girian Fish Market, 27 September 2010 (Peristiwady, 2011);
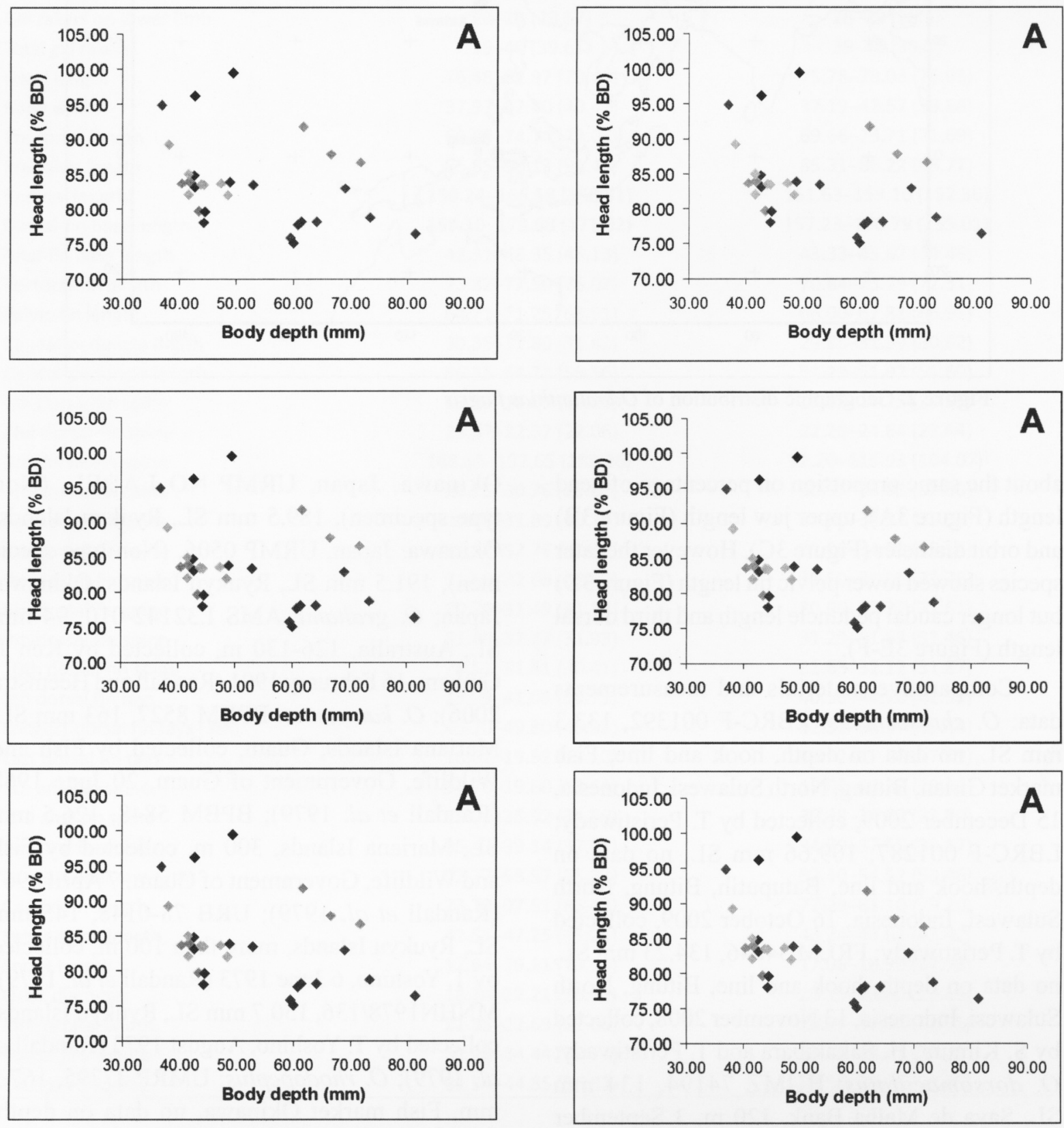

Figure 3. Ratio of head length (A), upper jaws length (B), orbit diameter (C), pelvic fin length (D), caudal peduncle length (E) and third dorsal spine length (F) of nine species. Odontanthias chrysostictus (blue); O. dorsomaculatus (black); O. flagris (red); O. grahami (pink); O. katayamai (brown); O. rhodopeplus (light grey); O. tapui (light blue); O. unimaculatus (light brown); O. wassi (green) 
Odontanthias wassi: BPBM 29373 (holotype), 1 specimen, $121.0 \mathrm{~mm} \mathrm{SL}$, American Samoa, Ofu Island, off Ofu Village, about 100 meters, hook and line, collected by Paul Pedro (local fishermen), 2 September 1983;

\section{ACKNOWLEDGEMENT}

The materials in this paper are collected during the program of Fish Biodiversity of the Coral Reef Ecosystems at Coral Triangle's, financed by the Minister of Sciences and Technology and Indonesian Institutes of Sciences, 2010. I express my gratitude to Prof. K. Matsuura (NSMT, Japan) who has been considered as the author's supervisor, to Prof. S. Kimuras (FRLM, Mie, Japan) who provided the holotype of Odontanthias wassi from BPBM, Honolulu.

\section{REFERENCES}

Bleeker, P. 1873. Sur Les Espèces Indo-Archipélagiques d'Odontanthias et de Pseudopriacanthus. Nederl. Tijdschr. Dierk., 4: 235-240.

Chen, J.P. and K.T. Shao. 2002. Plectranthias sheni, a New Species and P. kamii, a New Record of Anthiine Fishes (Perciformes: Serranidae) from Taiwan. Zoological Studies, 41(1): 63-68.

Eschmeyer, W.N. and R. Fricke (eds). 2012. Catalog of Fishes Electronic Version (12/01/2012). http:// research.calacademy.org/research/ichthyology/ catalog/fish-catmain.asp.

Katayama, M. and E. Yamamoto. 1986. The Anthiine Fishes, Odontanthias dorsomaculatus sp. nov. and Plectranthias bauchotae Randall, from the Western Indian Ocean. Jap. Jour. Ichthyology, 32 (4): 387-390.

Kimura, S., T. Peristiwady, and S.R. Suharti. 2003. Serranidae. In: Kimura, S. \& K. Matsuura (eds), Fishes of Bitung. Northern tip of Sulawesi, Indonesia. Ocean Research Institute, University of Tokyo, Tokyo, p. $46-56$.
Kuiter, R.H. and H. Debelius. 2006. World Atlas of Marine Fishes. Ikan-Unterwasseerarchiv, Waldshulstrasse, Frankfurt, Germany, 357 pp.

Masuda, H., K. Amaoka, C. Araga, T. Uyeno, and T. Yoshino. 1984. The fishes of the Japanese Archipelago. Tokyo, Japan: Tokai Univ. Press, $370 \mathrm{pp}$

Peristiwady, T. 2006. Economical Important Fish of Indonesia: Fish Identification Guidebook. LIPI Jakarta: Press, Indonesian Institute of Sciences, 270 pp. (in bahasa Indonesia).

Peristiwady, T. 2011. First Record of Odontanthias unimaculatus (Tanaka 1917) (Perciformes: Serranidae) from Indonesia. Biodiversitas, 12 (3): $136-140$

Randall, J.E. 1996. Two New Anthiine Fishes of the Genus Plectranthias (Perciformes: Serranidae), with a Key to the Species. Micronesica, 29: $113-131$

Randall, J.E. and P.C. Heemstra. 2006. Review of the Indo-Pacific Fishes of the Genus Odontanthias (Serranidae: Anthinae), with Descriptions of Two New Species and Related New Genus. Indo-Pacific Fishes, 38: 1-31.

Randall, J.E., L.A. Maugé, and Y.B. Plessis. 1979. Two New Anthiine Fishes of the Genus Holanthias from the Southern and Western Pacific. Jap. Jour. Ichthyology, 26 (1): 17-25.

Smith, M.M. and P.C. Heemstra (eds). 1986. Smiths Sea Fishes. Johannesburg: Macmillan South Africa, 1047 pp., 144 plates.

White, W.T. 2011. Odontanthias randalli n. sp., a New Anthiine Fish (Serranidae: Anthiinae) from Indonesia. Zootaxa, 3015: 21-28. 